Ann. Génét. Sél. anim., 1982, 14 (1), 29-42

\title{
Coat colour variants of village pigs in Papua New Guinea
}

\author{
J.J. LAUVERGNE, G.L. MALYNICZ *, A.R. QUARTERMAIN ** \\ I.N.R.A., Laboratoire de Génétique factorielle, \\ C.N.R.Z, F 78350 Jouy-en-Josas \\ * Livestock Division, Department of Primary Industry, \\ P.O. Box 2417, Konedobu P.N.G. \\ ** Faculty of Agriculture, University of Papua New Guinea, \\ P.O. Box 793, Lae P.N.G.
}

\begin{abstract}
Summary
A prelimincry description and genetic analysis of coat colour variation in Papua New Guinea village pigs is presented. Data were obtained from a series of deliberate matings and from surveys of coat coloration in two villages. A number of pigmentary variations caused by alleles at the Agouti, Extension and Brown loci were found and are described, including a possible new allele at the Brown locus $\left(B^{k}\right)$ causing brown spots on the basic red background colour. The segregations observed in the deliberate matings can be interpreted in terms of two alleles at the Agouti ( $A^{w}$ and $a$ ) and two at the Extension loci $\left(E^{+}\right.$and $\left.E^{p}\right)$. Results from the village surveys show a high incidence of agouti phenotypes $\left[A^{w}\right]$, relative to black $[a]$, and a very low incidence of white designs (belt or points). These results suggest a still small genetic influence of exotic pigs in the villages, in spite of deliberate distribution, provided that the allele causing black colour $(a)$ is present in the native Papuan stock. The allele $E^{p}$ (spotted) giving black patched on red (or secondarily white) background may also be considered as a part of the native stock. The results are consistent with a hypothesis concerning an early arrival of pigs in Papua New Guinea relatively soon after domestication, followed by a period of isolation.
\end{abstract}

\section{I. - Introduction}

The pig is the main domesticated livestock species in Papua New Guinea, despite the introduction over the last 50 years of cattle, goats and sheep (HoLmes, 1980).

Remains dating back 5000 years suggest that the pig was introduced by man during the introduction of agriculture (BULMER, 1966).

Disagreement exists as to the taxonomy of the native pig (ZEUNER, 1963; EPSTEIN, 1971) due to a lack of knowledge of its origins.

There are over one million village pigs in Papua New Guinea (DENSLEY et al., 1978), some of which are crossbred from the use of exotic breeds such as the 
Berkshire, Tamworth, Saddleback and Large White. Such crossbreeding, which has been encouraged by missions and the Department of Primary Industry (PURDY, 1971), could lead to a situation where the characteristics of the native pig become difficult to assess.

An initial study on the growth and carcass characteristics of the native pig was published by MALYNICZ (1973 a).

The present paper is devoted to a description and genetic analysis of coat colour variation in village pigs.

\section{II. - Résumé on genetics of coloration}

\section{General considerations on mammalian coat colour}

Coat colour in mammals is due to melanins, a family of pigments whose biochemical production is controlled by a few loci known by their mutants in many species : Albino $C$, Agouti A, Extension $E$ and Brown $B$.

The chemistry of coat colour genetics has been described recently by Prota \& Searle (1978). The Albino locus $(C)$ controls the first step in the oxydation of tyrosine, the basic raw material for melanin synthesis. The Agouti $(A)$ and Extension $(E)$ loci, working outside the melanocyte $(A)$ and within the melanocyte $(E)$ respectively, control regional and total extension of eumelanins (black or brown) and phaeomelanin (yellow/red) in the body and in individual hairs. The mutants at the $B$ locus affect eumelanin only, changing black to brown.

Besides these main basic pigmentation loci there are several other loci where mutants may affect the coat colour in various ways.

\section{Coat colour in the pig}

The genetics of coat colour in the pig has been reviewed by SEARLE (1968), Adalsteinsson (1974), and more recently, by Ollivier \& Sellier (1982). Variants at the $\operatorname{Agouti}(A)$ and Extension $(E)$, as well as at loci for Dilution (D), White $(I)$ and White belt $(\mathrm{Be})$ have been detected. This species is also characterised by a variegated allele of Extension which gives black patches on a red background. This pattern can be confused with black piebaldness if the red colour background disappears.

\section{III. - Materials and methods}

1. In 1974, an experiment was set up at the Tropical Pig Breeding and Research Center, Goroka, in the Eastern Highlands to examine the inheritance of coat colour in native pigs. Three breeding groups, consisting of agouti (wild), black and spotted pigs, were established. 
Agouti was defined according to DE FREDRICK (1971) as a pattern characterised by juvenile striping and a "grey » body in the adult stage with zonated hair : black, yellow, black. Spotted was taken to include black patches on a white or red background.

2. In 1980, a small survey of village pig coat colouration was carried out at Ngasawampum village, $25 \mathrm{~km}$ West of Lae in the Markham Valley of the Morobe Province (67 pigs) and at Kenewenka village, $25 \mathrm{~km}$ North of Goroka in the Eastern Highlands Province at an altitude of about $1800 \mathrm{~m}$ (40 pigs).

This survey was done in order to check the range of phenotypic variation and to make an initial evaluation of the phenotypic frequencies of pig coat colour patterns in the villages.

3. Some results from crossbreeding at the experimental pig unit of the Faculty of Agriculture, University of Papua New Guinea in Lae, which were collected in 1980, were added to the Goroka results.

Figure 1 shows the geographic situations mentioned.

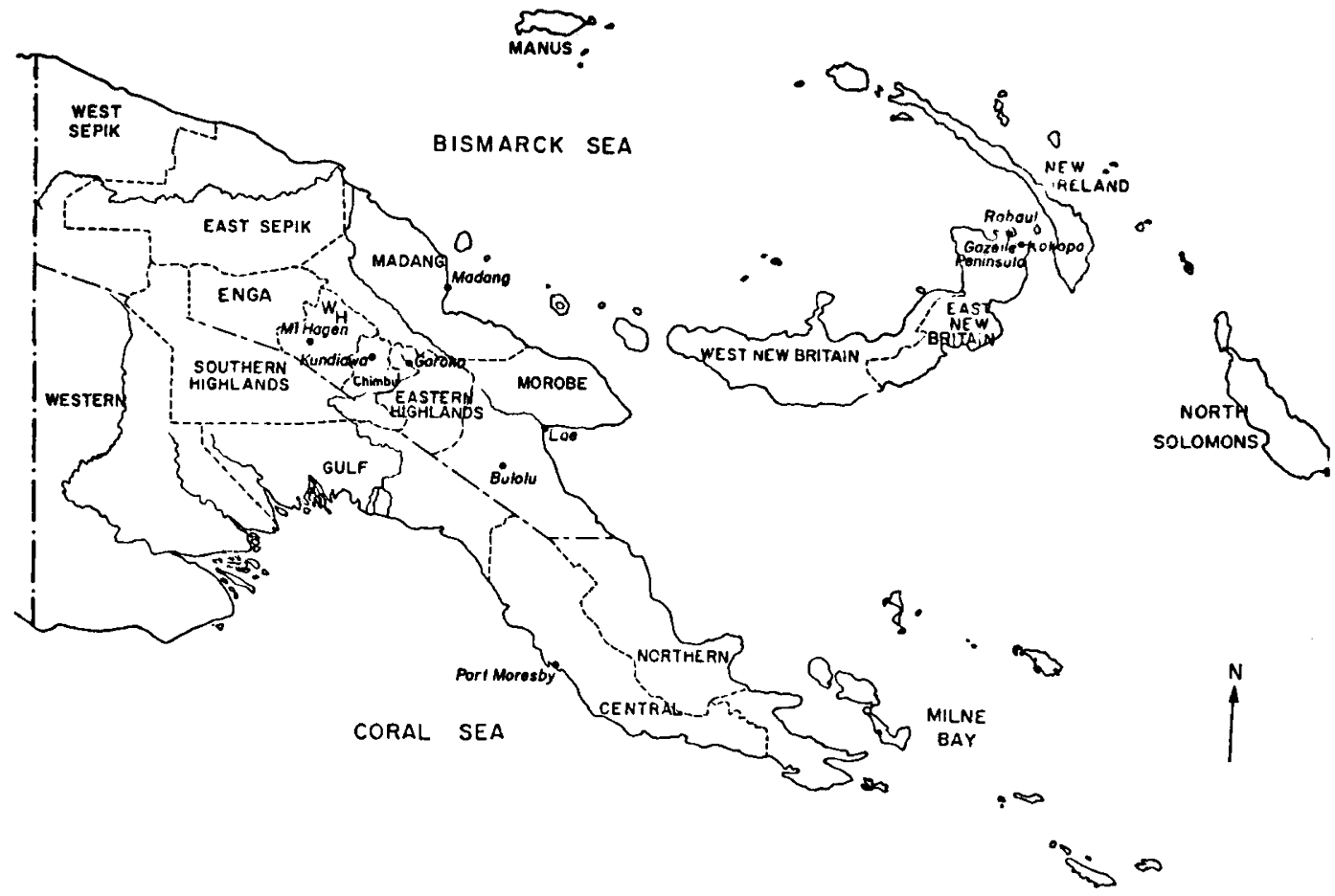

FIG. 1

The geographic locations in Papua New Guinea cited in the text. Localisation géographique des lieux cités dans le texte, en Papoucsie Nouvelle Guinée. 
4. To facilitate a more exact description of the colouration of the European wild pig than that found in the literature (Searle, 1968 ; SNethlage, 1980) and a comparison with the agouti colouration found in the Papua New Guinea pig, two examinations of wild pig populations were performed (by J.J. LAUVERGNE) in France. The first was in Chambord Park (Loir-et-Cher) after game cropping and the second was on a private station breeding wild pigs at La Lauze (Vaucluse, S.E. of France).

\section{IV. - Results and discussion}

A. - The phenotypes and their genotypic interpretation

\section{Basic pigmentation phenotypes}

\section{a) Descriptive results}

The definition of black and spotted pigs used in 1974 was found to be satisfactory as a basic for classification in 1980 (fig. 2 a and 2 b). In the latter survey, a variant of spotted was seen in which the black patches are replaced by brown ones, the back-ground remaining white or red (fig. 2 c).

For adult agouti pigs in Papua New Guinea, the main pattern may be named "white belly agouti »: the body is agouti grey (i.e. with zonated black-yellow-black hair) with a light belly and a white snout (fig. $2 \mathrm{~d}$ ).

Some minute variations are observed in this pattern. Sometimes the white designs are not well marked. Occasionnally black patches in the skin give the appearance of «black spotted agouti».

A more important variation may be seen with the replacement of the light belly of the previous pattern by black, the disappearance of the white snout and the presence of some black on the underjaws, legs and mane (fig. $2 \mathrm{e}$ ). This pattern is homologous in appearance with the «badger face» pattern of sheep and goats (see Adalsteinsson, 1970 ; LaUVergne, 1978).

In the juvenile stage, agouti animals are characterized by a longitudinally striped coat, black and yellow (fig. $2 \mathrm{f}$ ). Between animal variation and the age of attainment of the adult coat are yet to be described and defined.

\section{b) Genotypic interpretation}

a) Spotted. Previously what has been called «spotted》 in this study was known as «black spotting» (in French «domino»; LAUvergne \& CANOPE, 1979) and is considered to be the effect of the variegated allele at the Extension locus, as mentioned above, and not that of an allele at a locus for piebaldness.

Homologous situations are found in the guinea pig, rabbit, bovine and dog (SEARLE, 1975). The allele inducing «spotted " in the breeds of the western world has been named $e^{j}$ or $E^{P}$. 

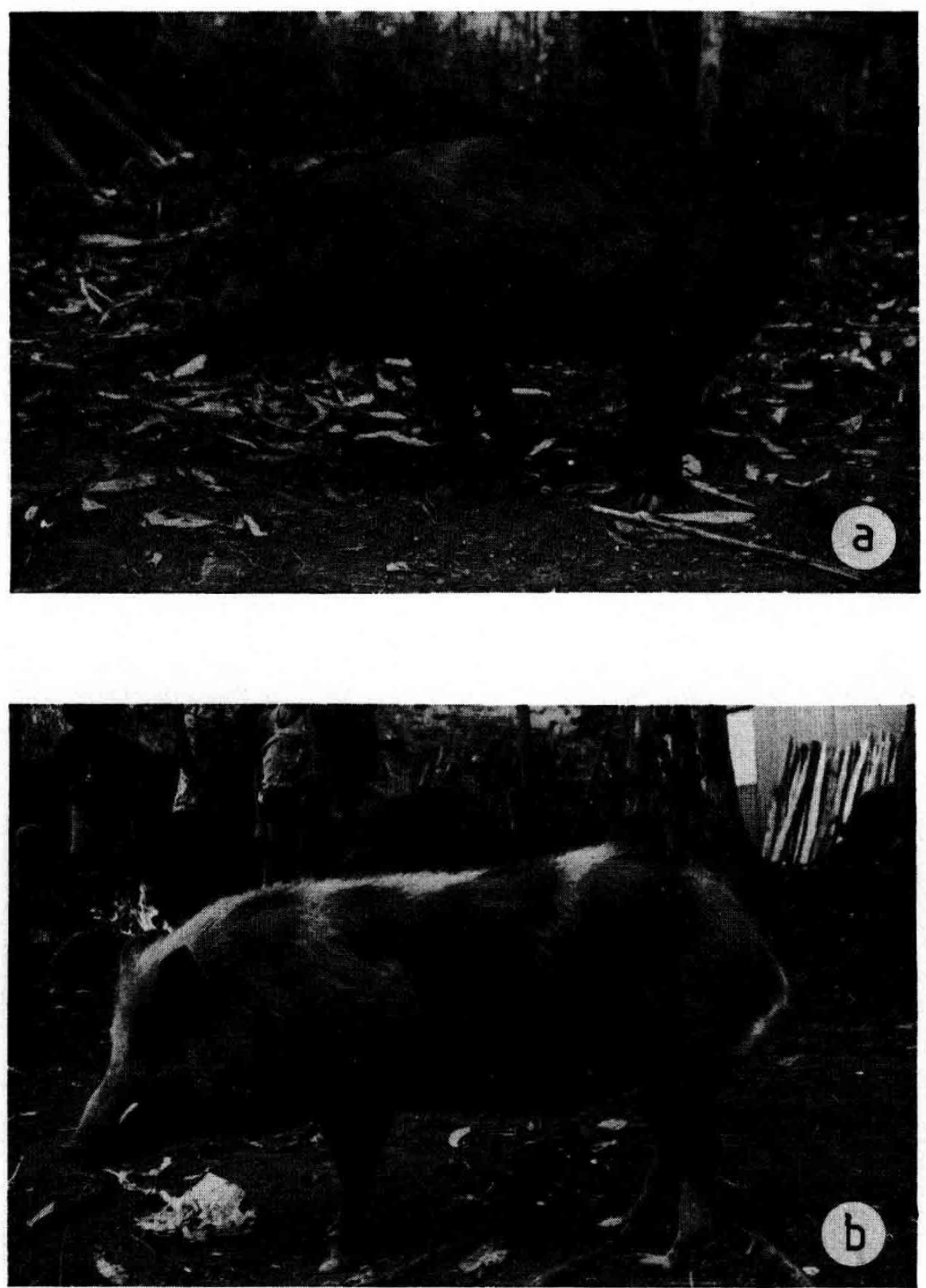

FIG. 2.

The pigmentation phenotypes of Papua New Guinea pigs.

Les phénotypes pigmentaires des porcs de Papouasie Nouvelle Guinée.

a) Black.

Noir.

b) Black spotted.

Domino noir. 

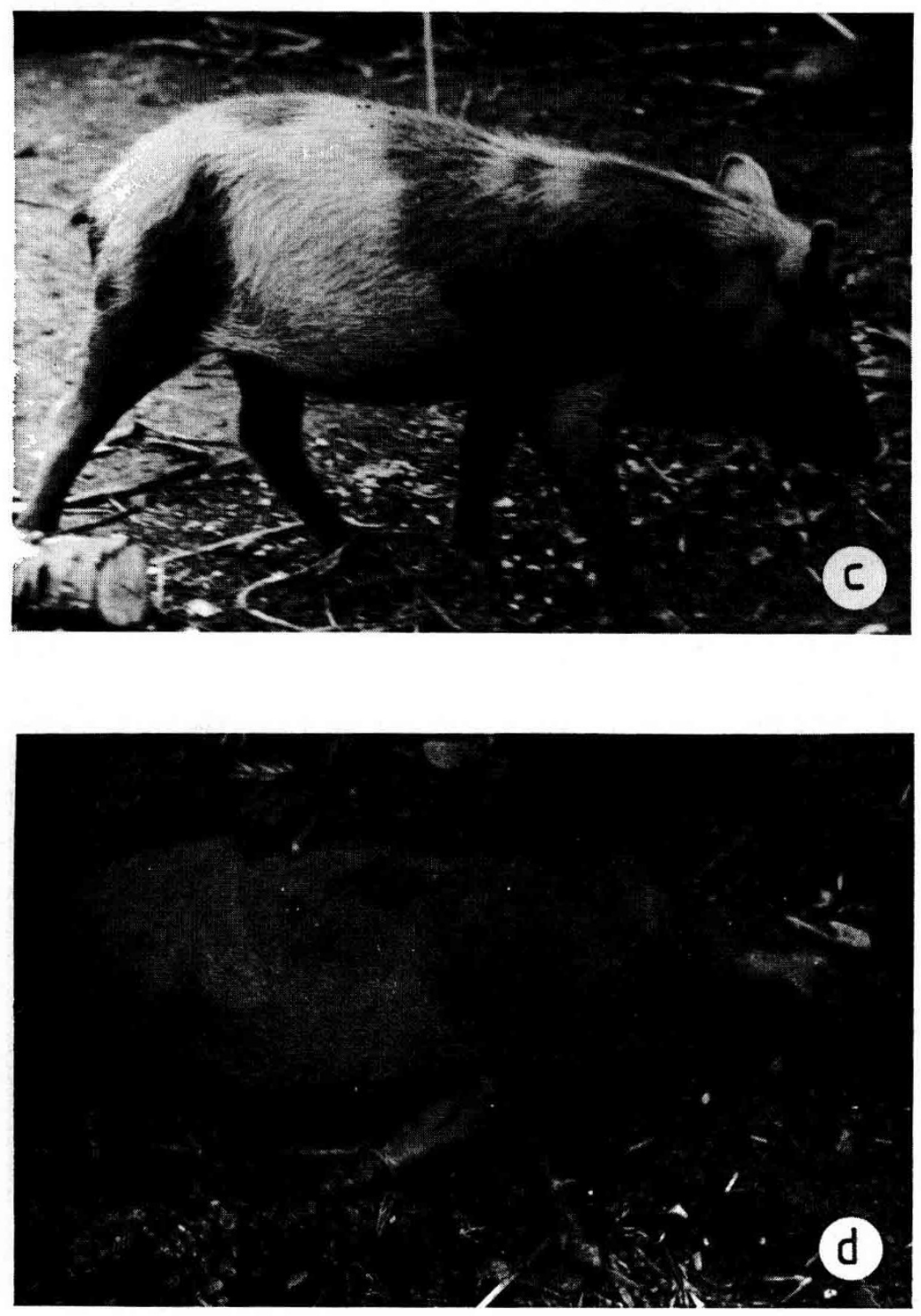

Fig. 2 (suite)

c) Brown spotted.

Domino brun.

d) Agouti white belly.

Agouti ventre clair. 

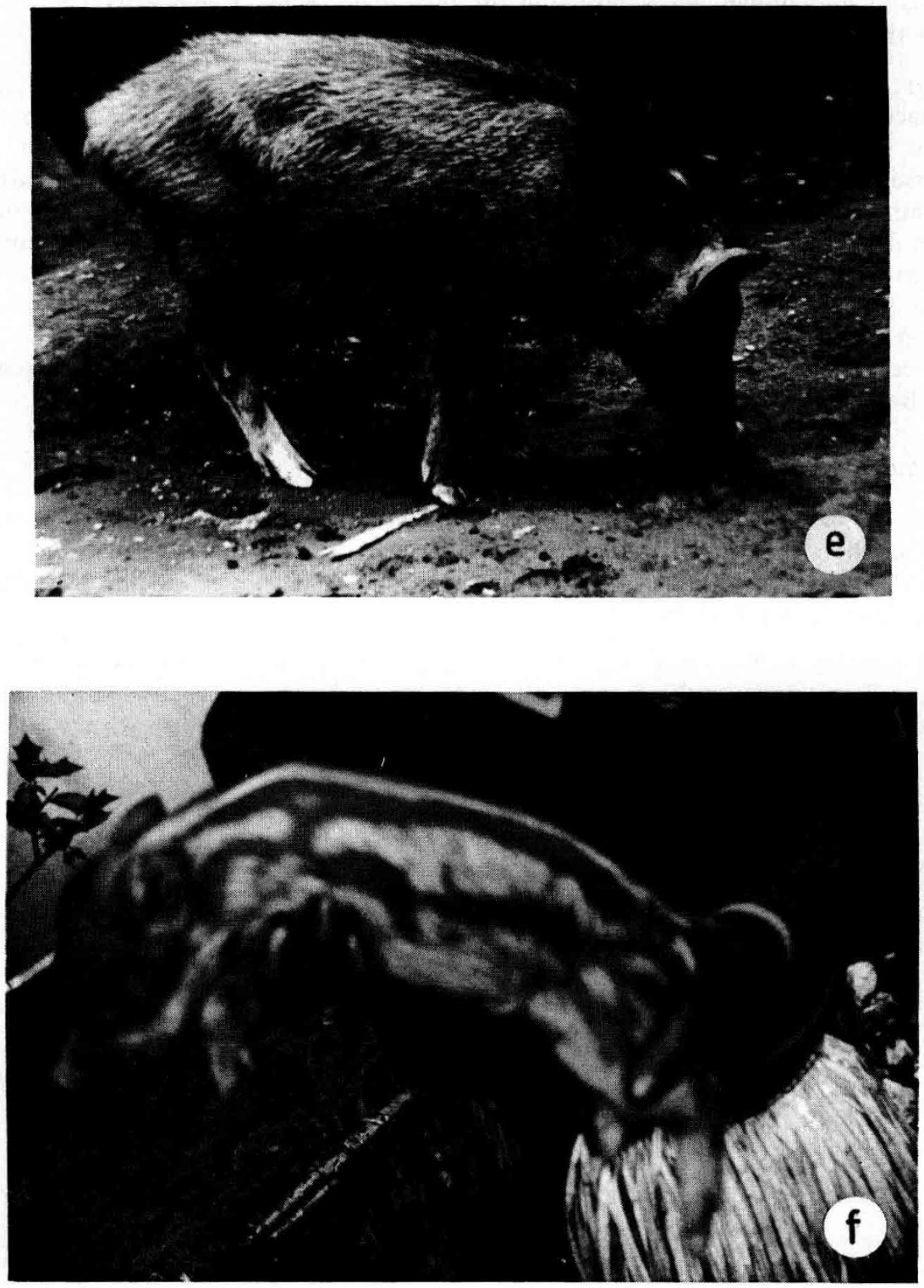

FIG. 2 (suite)

e) Badger face.

Blaireau.

f) Juvenile striping in agouti pattern.

Livrée juvénile des patrons agouti. 
B) Brown spotted. The most likely interpretation for the brown spotted pigs seen in 1980 is an allele at the $B$ (Brown) locus, probably recessive, transforming black eumelanin into brown. $B^{k}$ is proposed for this allele ( $k$ for Kenewenka : the village where this variation was identified for the first time).

y) Agouti. A preliminary interpretation is that the agouti white belly pattern is induced by the wild type allele at the Agouti locus : "white belly 》, symbol $A^{w}$. This is the interpretation proposed by SEARLE (1968) who does not however seem to consider the possibility of variations in the wild pattern under the control of alternative genes at the Agouti locus. In France, where a phenotype very similar to the Papua New Guinea agouti has been found at La Lauze, there is another wild pattern with uniform agouti-grey except for the underjaws, mane and legs having some black. The «badger face » type agouti described above may also be induced by another allele at the Agouti locus : $A^{b}$ (b for badger face). The early presence of the white belly agouti pattern in Papua is also suggested by a photograph from BREHM given in EPSTEIN (1971).

\section{White designs}

In the first samples in 1974 no white designs were included as they were rather scarce in the village population. In 1980, however, white belt and black with white points designs were observed. These variations may be attributed to the introduction of Saddleback and Berkshire pigs (fig. $3 \mathrm{a}$ and b).

According to Ollivier \& Sellier (1982), the belt is induced by the $B e$ allele which is dominant over the $b e$ wild allele. No name has been proposed for the allele inducing black with white points.

\section{Results}

\section{B. - Analysis of segregations}

In the 1974 data, no distinction was made between the agouti phenotypes. The results of the Goroka and Lae studies are given in table 1.

\section{TABLE 1}

The results of mating indigenous Papua New Guinea pigs of various colour patterns [GOROKA and LAE].

Résultat du croisement de porcs Papous indigènes de différentes couleurs [GoROKa et LAE].

\begin{tabular}{|c|c|c|c|c|c|c|c|c|c|}
\hline \multirow{3}{*}{ No. } & \multirow{3}{*}{ Type of crossing } & \multirow{3}{*}{$\begin{array}{c}\text { No. } \\
\text { of litters }\end{array}$} & \multirow{3}{*}{ No. } & \multicolumn{6}{|c|}{ Progeny } \\
\hline & & & & \multicolumn{2}{|c|}{ Black } & \multicolumn{2}{|c|}{ Spotted } & \multicolumn{2}{|c|}{ Agouti } \\
\hline & & & & No. & $\%$ & No. & $\%$ & No. & $\%$ \\
\hline 1 & Black $\times$ Black & 6 & 35 & 26 & 74.3 & 8 & 22.9 & 1 & 2.9 \\
\hline 2 & Agouti $\times$ Agouti & 4 & 21 & 0 & 0 & 5 & 23.8 & 16 & 76.2 \\
\hline 3 & Spotted $\times$ Spotted & 4 & 24 & 0 & 0 & 21 & 87.5 & 3 & 12.5 \\
\hline 4 & Spotted $\times$ Agouti & 4 & 29 & 2 & 6.9 & 6 & 20.7 & 21 & 72.4 \\
\hline 5 & Black $\times$ Agouti .. & 2 & 6 & 4 & 66.7 & 1 & 16.7 & 1 & 16.7 \\
\hline
\end{tabular}



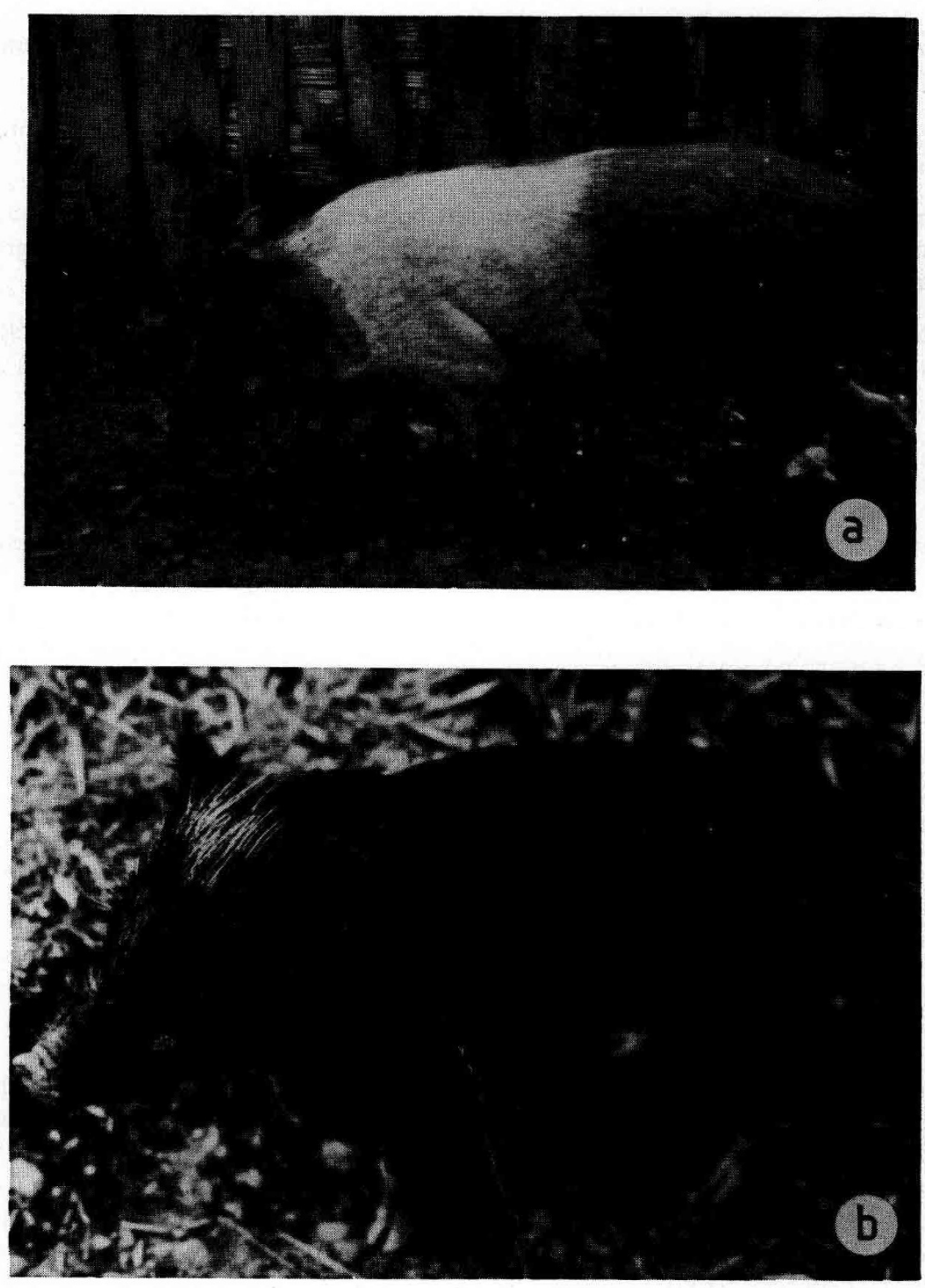

FIG. 3

White designs in Papua New Guinea pigs.

Phénotypes panachés des porcs de Papouasie Nouvelle Guinée.

a) White belt.

Ceinture blanche.

b) White points.

Points blancs. 


\section{Interpretation}

The segregations in table 1 may be interpreted with a dihybridism hypothesis :

- in Agouti, two alleles : $A^{w}$ and a self black, $a$;

- in Extension, two alleles : $E^{+}$(wild) and $E^{P}$ (variagated or spotted), provided it is admitted that the agouti piglet of line 1 (table 1) is a mistake.

The dominance and epistacy relationships between these alleles may be interpreted as in table 2 where the phenotypes corresponding to various genotypes are given in accordance with the phenotypes observed in the matings shown in table 1.

The phenotypes of $A^{w} A^{w} E^{+} E^{P}$ and $A^{w} A^{w} E^{P} E^{P}$ are probably mainly spotted, as $A^{w} a E+E^{P}$ is spotted.

TABLE 2

Dominance and epistacy relationships at the $\mathrm{A}$ and $\mathrm{E}$ loci to explain the results given in table 1.

Relation de dominance et d'épistesie aux loci A et E expliquant les rósultats du tableau 1.

\begin{tabular}{|c|c|c|c|}
\hline & $E+E+$ & $E+E^{p}$ & $E^{p} E^{p}$ \\
\hline$A^{w} A^{w} \ldots$ & $\begin{array}{c}\text { Agouti } \\
\text { (by definition) }\end{array}$ & Agouti or Spotted & Agouti or Spotted \\
\hline$A^{w} a \ldots$ & $\begin{array}{c}\text { Agouti } \\
\text { (by definition; }\end{array}$ & $\begin{array}{c}\text { Agouti or Sputted } \\
\text { (lines } 3,4)\end{array}$ & $\begin{array}{c}\text { Agouti or Spotted } \\
\text { (lines } 3,4)\end{array}$ \\
\hline$a a$. & $\begin{array}{c}\text { Black } \\
\text { (line 1) }\end{array}$ & $\begin{array}{l}\text { Black } \\
\text { (line 1) }\end{array}$ & $\begin{array}{l}\text { Spotted } \\
\text { (line 1) }\end{array}$ \\
\hline
\end{tabular}

Such an interpretation of experiments made with few animals and which does not take account of possible incomplete dominance must be considered with caution. However, a study of the literature on pig colouration has not revealed any studies on epistatic relationships between loci $A$ and $E$ (see Searle, 1968 and Ollivier \& Sellier, 1982). Such experiments need to be carried out with lines whose genotypes are known perfectly. For example the lack of black phenotypes among the progeny of matings between agouti parents could simply result from lack of heterozygotes in the parental sample or recombination sampling rather than a wrong hypothesis.

\section{C. - Phenotypic frequencies}

The results of the 1980 village survey are shown in table 3 .

The results show a high incidence of agouti phenotypes in the two villages, relative to black. There is also a low incidence of white designs. 
TABLE 3

Distribution of animals according to pigmentation phenotype and white design in two villages of Papua New Guinea.

Distribution des animaux selon leur phénotype pigmentaire et panaché dans deux villages de Papouasie Nouvelle-Guinée.

\begin{tabular}{|c|c|c|c|c|c|}
\hline & & \multicolumn{2}{|c|}{$\begin{array}{l}\text { Ngasawampum } \\
\text { sampling } \\
\text { (Morobe) }\end{array}$} & \multicolumn{2}{|c|}{$\begin{array}{c}\text { Kenewenka } \\
\text { sampling } \\
\text { (Eastern Highlands) }\end{array}$} \\
\hline & & No. & $\%$ & No. & $\%$ \\
\hline \multirow[t]{6}{*}{ Pigmentation } & Agouti ....... & 50 & 75.7 & 16 & 40.0 \\
\hline & Spotted : & & & & \\
\hline & - brown & 0 & - & 3 & 7.5 \\
\hline & - black .......... & 7 & 10.6 & 10 & 25.0 \\
\hline & Black ............. & 9 & 13.6 & 11 & 27.5 \\
\hline & TOTAL $\ldots \ldots \ldots$ & 66 & & 40 & \\
\hline \multirow{6}{*}{ White design } & Uniform $\ldots \ldots \ldots \ldots$ & 63 & 94.0 & 38 & 95.0 \\
\hline & White points $\ldots \ldots \ldots$ & 0 & - & 0 & - \\
\hline & White belt $\ldots \ldots \ldots \ldots$ & 2 & 3.0 & 1 & 2.5 \\
\hline & White feet $\ldots \ldots \ldots$ & 1 & 1.5 & 1 & 2.5 \\
\hline & All white $\ldots \ldots \ldots \ldots$ & 1 & 1.5 & 0 & - \\
\hline & TOTAL $\ldots . .$. & 67 & & 40 & \\
\hline
\end{tabular}

As both villages are close to major centers of exotic pig distribution, and as most distributed pigs are black with white designs (Berkshire or Saddleback), red (Tamworth) or white (Large White/Landrace), the low incidence of the piebald and white as well as the absence of red phenotypes suggests a small genetic influence of exotic pigs at the village level. The black allele must be considered as present in the native Papuan stock.

This low proportion of exotic phenotypes is consistent with a high mortality recorded among exotic pigs distributed into the village environment in the early seventies. Average mortality was 30 percent within six months of arrival (MALYNICZ, 1973 b).

In Vanuatu, QUARTERMAIN (1981) noticed a high frequency of black and agouti phenotypes, relative to red, spotted or white phenotypes, particularly among feral pigs and in inland villages. DE FREDRICK $(1971,1977)$ points out the universality of agouti pigs in the Solomon Islands and that black and spotted pigs are also common. In both countries it is probable that the influence of exotic introductions has been greater than in mainland Papua New Guinea since white and red pigs are not uncommon in coastal locations or on certain islands. 


\section{V. - Final discussion and conclusion}

The situation is consistent with an early arrival of pigs in Papua New Guinea (see BULMER, 1966) relatively soon after their domestication in the Middle East (IsAAC, 1970 ; BöKöNYI, 1976: $7000 \mathrm{BC}$ ), when few colour mutants ( $a$ and $E^{P}$ ) had yet arisen, followed by a period of isolation with the appearance of new mutants such as $B^{k}$ in $B$. In that respect the situation is similar to that of the Sheep after its domestication, also in the Middle East, as analysed by LAUVERGNe (1979 a and b). Accumulations of variants with visible effects (mainly colour genes) can be used as markers to date when a given population started to migrate. In general, the first to migrate are the most archaic with the least variants and are found at the periphery.

More precise mendelian analysis is clearly needed and could be pursued by the creation of pure and segregating lines of native pigs. Work is needed to :

1) study allelism and dominance in the various series : Agouti, Extension, Brown;

2) analyse epistatic behaviour, especially between Agouti and Extension genotypes ;

3) study all new variants that have arisen or can be found.

The other conclusion from this study is that the allelic situation, with exotic breeds carrying alleles different to those of native populations, provides an easy way to measure the degree of genetic invasion by exotic genotypes, as seen above. Such measurement of colour gene or phenotype frequencies has already been proposed by CASABIANCA and MolÉnAt (1977) for the native pig of Corsica which is facing upgrading by the Large White. In Corsica the frequency of white phenotypes was used, while in Papua New Guinea the frequencies of white designs and red colouration can be used.

$$
\text { Received for publication in January } 1982 .
$$

\section{Acknowledgments}

The manuscript has been read by the $\mathrm{D}^{\mathrm{rs}}$ Ph. Dreux (E.N.S. Zoologie, Paris) et S. Adalsteinsson (Agricultural Research Institute, Reykjavik, Iceland) who have suggested useful improvements. Thanks are also due to the managers of Chambord Park and La Lauze breeding unit.

\section{Résumé}

Variants colorés du porc villageois de Papouasie Nouvelle-Guinée

Il s'agit d'une description et d'une étude génétique préliminaires de la variation colorée des porcs villageois de Papouasie Nouvelle-Guinée. Les données proviennent d'une série de croisements expérimentaux et d'observations dans deux villages. Les variations observées sont attribuées à des allèles contrôlant la pigmentation proprement dite aux loci Agouti, Extension et Brun avec, pour ce dernier locus, un possible mutant $B^{k}$ induisant 
des taches brunes sur fond rouge. Les ségrégations observées dans les croisements expérimentaux ont été interprétées en terme de biallélismes en Agouti $\left(A^{w}\right.$ et $a$ ) et en Extension $\left(E+\right.$ et $\left.E^{p}\right)$. Les résultats des enquêtes villageoises montrent une fréquence élevée du phénotype Agouti $\left[A^{w}\right]$ par rapport au phénotype noir $[a]$ et une fréquence très basse des dessins blancs (ceinture ou points blancs). Ces résultats suggèrent que l'in.luence génétique résultant de l'introduction de races exotiques dans les villages est encore très faible en dépit de distributions encouragées, à condition que l'on admette que l'allèle $a$ pour la couleur noire est un élément du stock autochtone. L'allèle $E^{p}$ (domino) qui donne des taches noires sur fond rouge (ou secondairement blanc) peut aussi être considéré comme faisant partie du stock indigène papou. Ces résultats s'accordent avec l'hypothèse d'une arrivée précoce du porc dans l'île, relativement peu de temps après sa domestication. Ensuite il $\mathrm{y}$ a eu une période d'isolement.

\section{References}

AdAlsteinsson S., 1970. Colour inheritance in Icelandic Sheep and relation between colour, fertility and fertilisation. J. agric. res. Icel., 2, 3-135.

Adalsteinsson S., 1974. Colour inheritance in farm animals and its application in selection. 1rst World Congress on Genetics applied to Livestock Production, Madrid, 1; 29-37.

BöKöNYı S., 1976. Development of early stock rearing in the Near East. Nature, 264 (5581), 19-23.

Bulmer Susan, 1966. Pig bone from two archaelogical sites in the New Guinea highlands. J. Polynesian Soc., 75, 504-505.

Casabianca F., Molénat M., 1977. Enquête sur les reproducteurs porcins Corses. I.N.R.A., $26 \mathrm{p}$.

DE Fredrick D.F., 1971. Pig Raising in the British Solomon Islands Protectorate. Agricultural Information Service, Department of Agriculture, Honiara.

DE FREDRICK D.F., 1977. Pig production in the Solomon Islands. I - Village pig production. Trop. Anim. Hlth. Prod., 9, 113-123.

DENSLEY et al., 1978. Livestock. Agriculture in the Economy. A series of review papers. D.P.I, Port Moresby.

Epstein H., 1971. The Origin of the Domestic Animals of Africa. Africana Publ. Co, New York, 2, 318-319.

Holmes J.H.G., 1980. Animal genetic resources in Papua New Guinea. Proc. Sabrao Workshop on Animal Genetic Resources in Asia and Oceania. Ministry of Agric. Japan, 439-468.

IsAAC E., 1970. Geography of Domestication. Prentice Hall, Englewood Cliffs.

LAUVERGNe J.J., 1978. Gènes de coloration du pelage de chèvres Alpines Chamoisées et Poitevines. Ann. Génét. Sél. anim., 10, 181-190.

LAUVERGNe J.J., 1979 a. Modèles de répartition des populations domestiques animales après migration par vagues à partir d'un centre d'origine. Ann. Génét. Sél. anim., 11, 105-110.

LAUVERGNE J.J., 1979 b. Visible genetic markers in domestic sheep and their ancestors. In : FooTE W.C. and BUNCH T.D. The Domestication of sheep : their ancestors, geography, time period and peope involved. International Sheep and Goat Institute, Logan, Utah, 21-23.

Lauvergne J.J., Canope I., 1979. Etude de quelques variants colorés du porc Créole de la Guadeloupe. Ann. Génét. Sél. anim., 11, 381-390.

MALYNiCZ G.L., 1973 a. Growth and carcass measurements of indigenous and exotic pigs raised in two housing systems in Papua New Guinea. Papua New Guinea Agric. J., 24, 23-25. 
Malynicz G.L., 1973 b. The productivity of exotic and indigenous pigs under village conditions. Part. 1. Papua New Guinea Agric. J., 24, 16-19.

Ollivier L., Sellier P., 1982. Genetics of pigs. Ann. Génét. Sél. anim. (sous presse).

Prota G., Searle A. G., 1978. Biochemical sites of gene action for melanogenesis in mammals. Ann. Génét. Sél. anim., 10, 1-8.

PuRdY D.J., 1971. Changing patterns in pig production in Papua New Guinea. Austr. Vet. J., 47, 481-484.

QuarTermain A.R., 1981. Report on an orientation mission to Vanuatu and New-Caledonia. Faculty of Agriculture, Univ. of P.N.G., Lae and French Embassy, Port Moresby, 18 p. roneotyped.

Searle A.G., 1968. Comparative genetics of coat colour in mammals. Logos Press, London.

SNeTHLAGE K., 1980. Le sanglier. Le Lorrain, Metz (précédente édition La Toison d'Or, 1954).

Zeuner F.E., 1963. A History of Domesticated Animals. Hutchinson, London. 